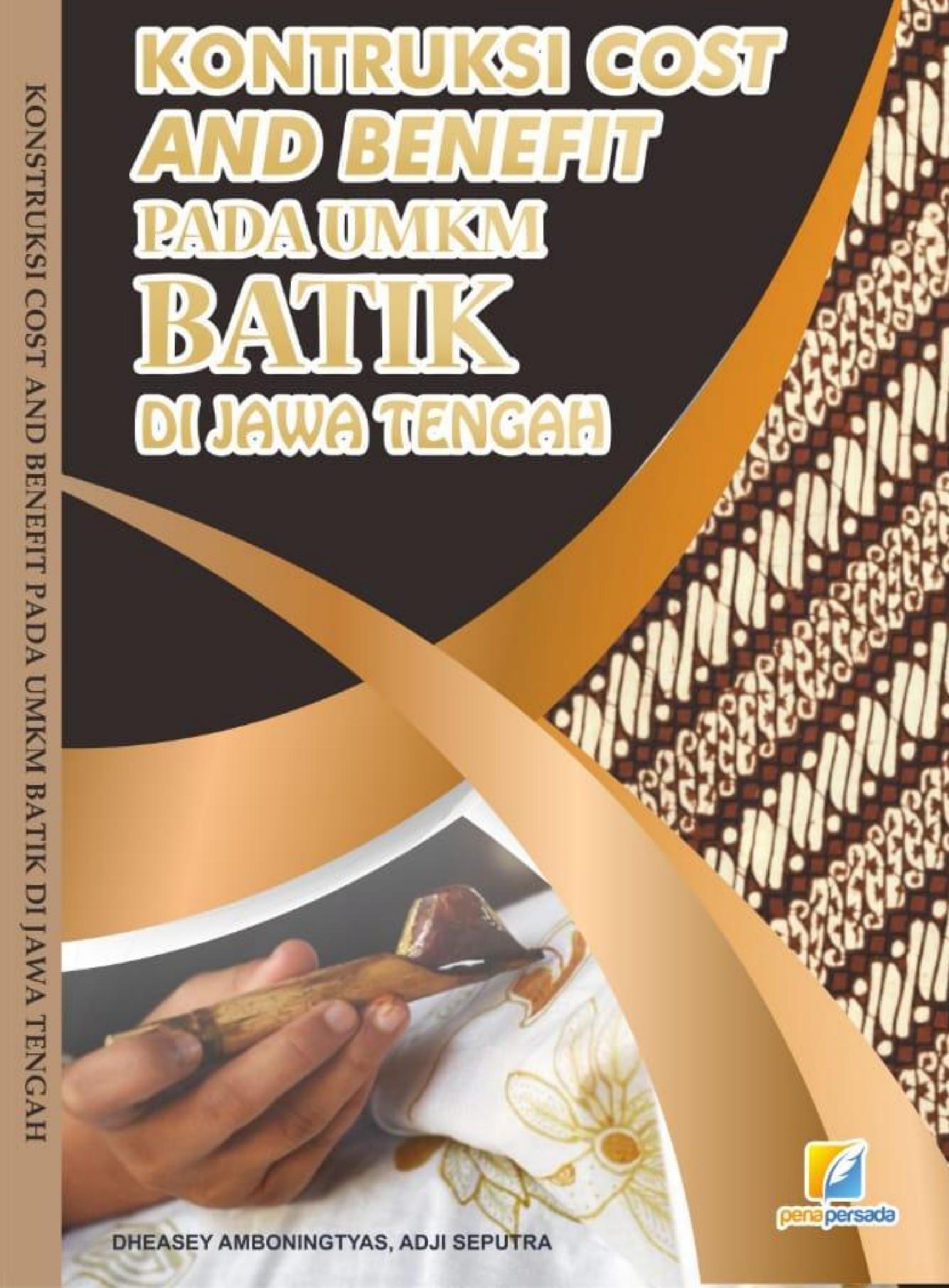




\section{KONSTRUKSI COST AND BENEFIT PADA UMKM BATIK DI JAWA TENGAH}

DHEASEY AMBONINGTYAS, ADJI SEPUTRA

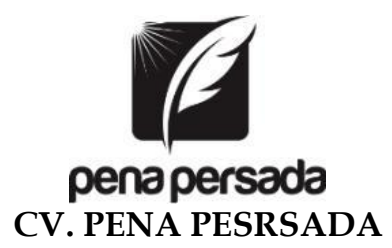




\section{KONSTRUKSI COST AND BENEFIT PADA UMKM \\ BATIK DI JAWA TENGAH}

\section{Penulis :}

Dheasey Amboningtyas, Adji Seputra

ISBN :978-623-6688-50-2

\section{Design Cover :}

Retnani Nur Briliant

\section{Layout :}

Hasnah Aulia

\section{Penerbit CV. Pena Persada}

Redaksi :

Jl. Gerilya No. 292 Purwokerto Selatan, Kab. Banyumas Jawa Tengah

Email : penerbit.penapersada@gmail.com

Website : penapersada.com

Phone : (0281) 7771388

Anggota IKAPI

All right reserved

Cetakan pertama : 2020

Hak cipta dilindungi oleh undang-undang.

Dilarang memperbanyak karya tulis ini dalam bentuk dan cara apapun tanpa ijin penerbit 


\section{KATA PENGANTAR}

Assalamualaikum Warahmatullahi Wabarakatuh.

Segala puji kami panjatkan kepada Allah SWT yang telah memberikan rahmat dan karunia-Nya kepada penulis, sehingga penulis dapat menyelesaikan buku ini. Buku ini disusun dalam rangka mempelajari konstruksi pendanaan keuangan UMKM Batik di Jawa Tengah yang berorientasi pada nilai cost and benefit CSR. Buku ini ditujukan untuk mahasiswa guna menunjang proses pembelajaran serta menjadi acuan bagi pemerintah untuk melakukan pengembangan konstruksi pendanaan keuangan UMKM Batik di Jawa Tengah yang berorientasi pada nilai cost and benefit CSR. . Penulis berharap dengan adanya buku ini dosen dan mahasiswa dapat terbantu dalam proses pembelajaran.

Penulis menyadari buku ini masih jauh dari kata sempurna, dan masih memerlukan perbaikan. Diharapkan para pembaca, dosen, dan mahasiswa dapat menambah menggunakan referensi pembelajaran yang lainnya. Kritik dan saran yang membangun guna penyempurnaan buku ini sangat penulis harapkan.

Semarang, Agustus 2020

penulis 


\section{DAFTAR ISI}

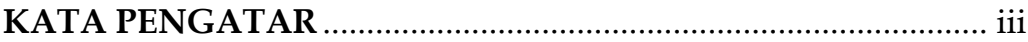

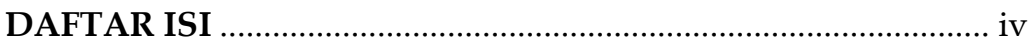

BAB I PENGEMBAGAN INKLUSI MODEL PENDANAAN

KEUANGAN UMKM BATIK DI JAWA TENGAH YANG BERORIENTASI PADA NILAI COST AND BENEFIT CSR (CORPORATE SOCIAL RESPONSIBILITY)

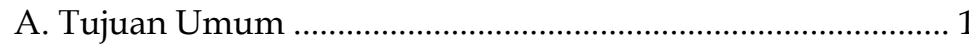

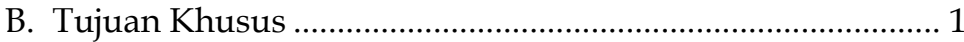

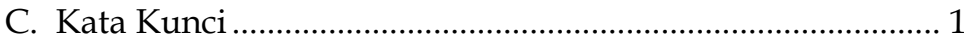

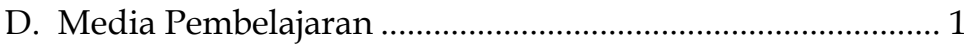

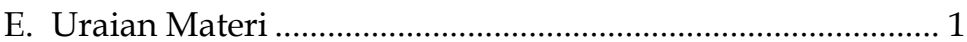

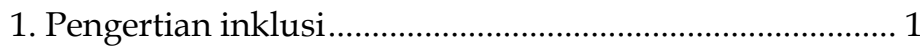

2. Tujuan inklusi ................................................................... 3

3. Pengertian nilai cost and benefit CSR ................................ 3

4. Tujuan nilai cost and benefit CSR .................................... 7

5. Menghasilkan Inovasi dan Pembelajaran untuk

Meningkatkan Pengaruh Perusahaan................................ 8

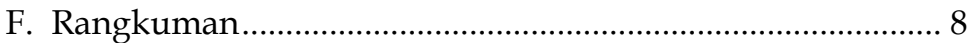

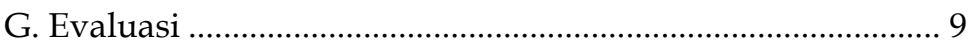

BAB II INKLUSI KEUANGAN DAN NILAI COST AND BENEFIT CSR

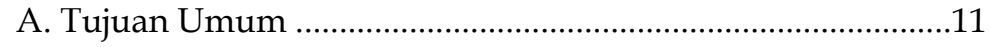

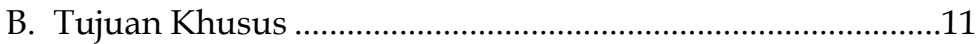

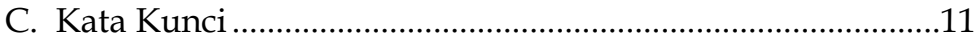

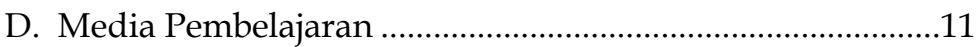

E. Uraian Materi ...........................................................................11

1. Pengertian inklusi keuangan ...........................................11

2. Gerakan inklusi keuangan .............................................12

3. Tujuan inklusi keuangan .................................................12

4. Pengertian nilai cost and benefit CSR .................................13

5. Tujuan nilai cost and benefit CSR ......................................14

6. Karakteristik nilai cost and benefit CSR ............................14

7. Keuntungan nilai cost and benefit CSR ..............................15 
8. Pengertian nilai cost and benefit csr ............................................ 16

9. Tujuan nilai cost and benefit CSR ........................................ 19

10. Karakteristik nilai cost and benefit CSR ............................. 20

11. keuntungan nilai cost and benefit CSR .............................. 20

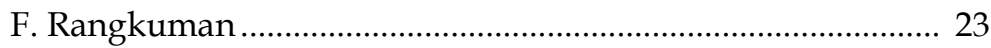

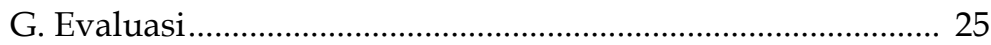

BAB III PENGEMBANGAN UMKM BATIK DI JAWA TENGAH YANG BERADA DI KAMPOENG BATIK LAWEYAN SOLO

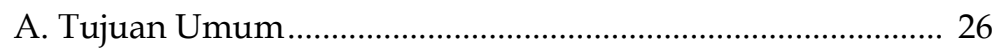

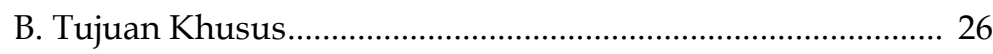

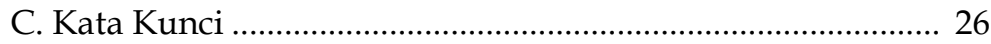

D. Media Pembelajaran............................................................ 26

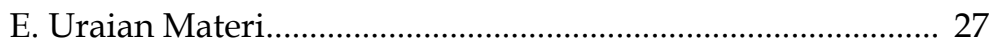

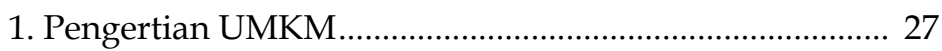

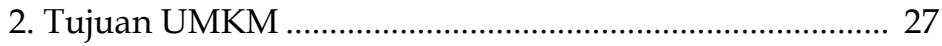

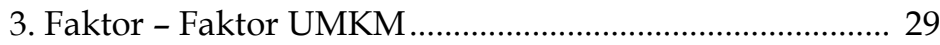

4. UMKM Batik Laweyan Solo ............................................... 30

5. Tujuan,Visi, dan Misi dari UMKM Batik Laweyan

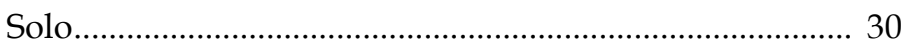

6. Struktur Organisasi Forum Pengembangan Kampoeng

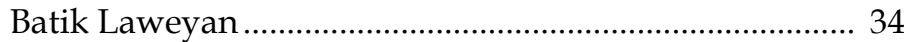

7. Bidang Usaha Kampoeng Batik Laweyan ........................ 36

8. Tempat dan Pengrajin Kampoeng Batik Laweyan.......... 36

9. Tempat dan Pengerajin Kampoeng Batik Laweyan........ 38

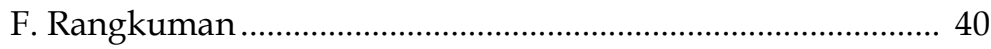

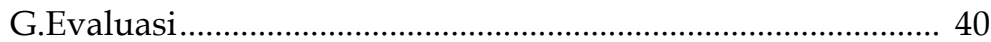

BAB IV PENGEMBAGAN UMKM BATIK DI JAWA TENGAH YANG BERADA DI KAMPOENG BATIK LASEM REMBANG

A. Tujuan Umum .............................................................. 42

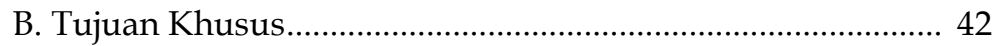

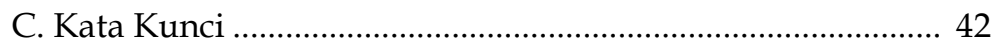

D. Media Pembelajaran............................................................. 42

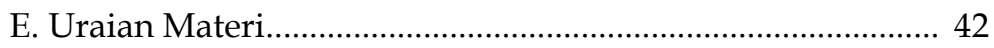

1. UMKM Batik Lasem Rembang ...................................... 42

2. Tujuan,Visi dan Misi dari UMKM Batik Lasem 
Rembang

3. Struktur Organisasi Forum Pengembangan Kampoeng Batik Lasem Rembang. 52

4. Bidang Usaha Kampoeng Batik Lasem Rembang........... 53

5. Tempat dan Pengerajin Kampoeng Batik Lasem

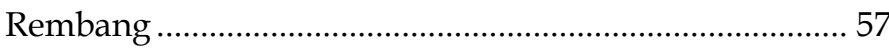

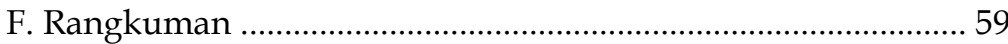

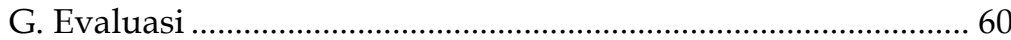

BAB V PENGEMBANGAN UMKM BATIK DI JAWA TENGAH YANG BERADA DI KAMPOENG BATIK KAUMAN PEKALONGAN

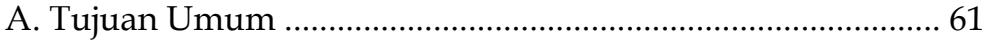

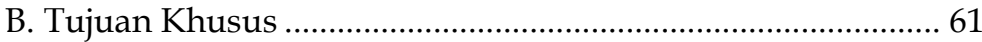

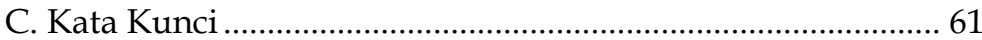

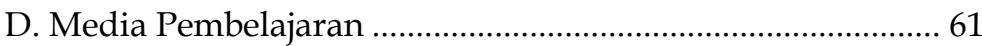

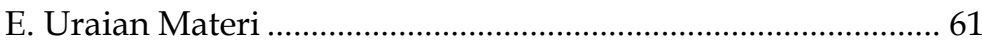

1. UMKM Batik Kauman Pekalongan..................................... 62

2. Tujuan,Visi dan Misi dari UMKM Batik Kauman

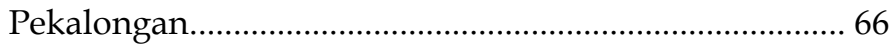

3. Struktur Organisasi Forum Pengembangan Kampoeng Batik Kauman Pekalongan ................................................. 67

4. Bidang Usaha Kampoeng Batik Kauman

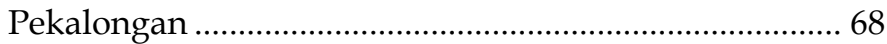

5. Tempat dan Pengerajin Kampoeng Batik Kauman

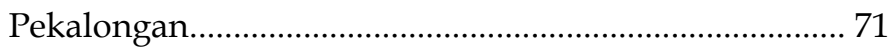

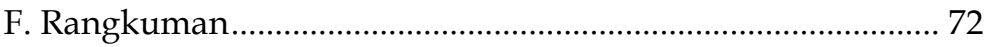

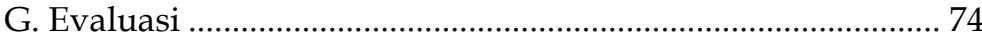




\section{BAB I \\ PENGEMBANGAN INKLUSI MODEL \\ PENDANAAN KEUANGAN UMKM BATIK DI \\ JAWA TENGAH YANG BERORIENTASI \\ PADA NILAI COST AND BENEFIT CSR \\ (CORPORATE SOCIAL RESPONSIBILITY)}

\section{A. Tujuan Umum}

Memahami materi ini sangat bermanfaat bagi mahasiswa untuk mengetahui pengembangan inklusi dalam model pendanaan keuangan UMKM batik di Jawa Tengah yang berorientasi pada nilai cost and benefit CSR

\section{B. Tujuan Khusus}

Setelah mempelajari bab ini, mahasiswa diharapkan dapat:

1. Menjelaskan inklusi.

2. Menjelaskan tujuan inklusi

3. Menjelaskan pengertian nilai cost and benefit CSR

4. Menjelaskan tujuan dari nilai cost and benefit CSR

\section{Kata Kunci}

Definisi pengertian inklusi, tujuan inklusi. definisi nilai cost and benefit CSR, tujuan nilai cost and benefit CSR.

\section{Media Pembelajaran}

Dalam bab ini media pembelajaran yang digunakan meliputi: white board, spidol, LCD, komputer.

\section{E. Uraian Materi}

\section{Pengertian inklusi}

Pengertian inklusi digunakan sebagai sebuah pendekatan untuk membangun dan mengembangkan sebuah lingkungan yang semakin terbuka, mengajak masuk dan mengikutsertakan semua orang dengan berbagai perbedaan latar belakang, karakteristik, kemampuan, status, kondisi, etnik, budaya dan lainnya. 
Inklusi membawa perubahan sederhana dan praktis dalam kehidupan masyarakat. Sebagai bagian dari masyarakat, kita menginginkan tinggal dalam lingkungan masyarakat yang memberikan rasa aman dan nyaman, yang memberikan peluang untuk berkembang sesuai minat \& bakatnya, sesuai cara belajarnya yang terbaik, yang mengupayakan kemudahan untuk melaksanakan kewajiban dan mendapatkan hak sebagai warga masyarakat.

Perubahan sederhana dan praktis menjadi ciri dari lingkungan inklusi. Dalam lingkungan inklusi, perubahan sederhana dan praktis merupakan upaya memudahkan setiap individu melakukan setiap kegiatannya dalam kehidupan sehari-hari. Contoh perubahan sederhana dan praktis :

a. Ada selokan yang terbuka di sepanjang jalan dan banyak batu-batu di pinggir selokan itu, perubahan apa yang bisa dilakukan oleh warga setempat?

b. Beberapa warga berpikir, menutup selokan adalah pekerjaan dari departemen pekerjaan umum, sikap mereka menunggu karena mereka tidak punya hambatan menggunakan jalan tersebut.

c. Beberapa warga lain seperti orangtua yang lanjut usia, anak-anak kecil di bawah usia sekolah, mereka yang baru terkena penyakit struk, mereka yang memiliki kesulitan melihat, mereka yang berjalan dengan menggunakan tongkat atau kursi roda atau ibu yang sedang hamil merasa kesulitan, tidak aman dan tidak nyaman menggunakan jalan tersebut.

d. Perubahan sederhana dan praktis yang diharapkan adalah :

1) Salah satu warga pergi melaporkan pada pihak yang mempunyai tugas perbaikan jalan

2) Sekelompok warga lainnya dapat bekerja sama menutup selokan dengan papan dan memindahkan batu-batu besar, sehingga setiap warga nyaman dan mudah menggunakan jalan tersebut. 


\section{Tujuan inklusi}

Inklusi keuangan memiliki banyak manfaat. Menurut Bank Dunia, peningkatan inklusi keuangan dengan nilai satu persen saja, maka pertumbuhan ekonomi bertambah 0,03 persen. Belum lagi efek lain dari inklusi keuangan dalam bentuk penciptaan lapangan pekerjaan, penurunan tingkat kemiskinan, hingga meminimalisir kesenjangan sosial. Selain itu, inklusi keuangan juga diharapkan mampu memberi sumbangsih lebih untuk negara, diantaranya sebagai berikut:

a. Mendukung stabilitas sistem keuangan

b. Meningkatkan efisiensi ekonomi

c. Mengurangi shadow banking atau irresponsible finance

d. Mendukung ekspansi pasar keuangan

e. Menyumbangkan potensi pasar baru bagi perbankan

f. Meningkatkan Human Development Index (HDI) Indonesia

g. Berkontribusi positif terhadap pertumbuhan ekonomi lokal dan nasional secara kontinu

\section{Pengertian nilai cost and benefit csr}

CSR adalah suatu tindakan atau konsep yang dilakukan oleh perusahaan sebagai bentuk tanggung jawab mereka terhadap sosial atau lingkungan sekitar dimana perusahaan itu berada. Sedangkan definisi CSR menurut World Business Council on Sustainable Development adalah komitmen dari bisnis/perusahaan untuk berperilaku etis dan berkontribusi terhadap pembangunan ekonomi yang berkelanjutan, seraya meningkatkan kualitas hidup karyawan dan keluarganya, komunitas lokal dan masyarakat luas. Wacana Tanggung Jawab Sosial Perusahaan(Corporate Social Responsibility) yang kini menjadi isu sentral yang semakin populer dan bahkan ditempatkan pada posisi yang penting, karena itu kian banyak pula kalangan dunia usaha dan pihak-pihak terkait mulai merespon wacana ini, tidak sekedar mengikuti tren tanpa memahami esensi dan manfaatnya. 
Program CSR merupakan investasi bagi perusahaan demi pertumbuhan dan keberlanjutan (sustainability) perusahaan dan bukan lagi dilihat sebagai sarana biaya (cost centre) melainkan sebagai sarana meraih keuntungan (profit centre). Program CSR merupakan komitmen perusahaan untuk mendukung terciptanya pembangunan berkelanjutan (sustainable development). Di sisi lain masyarakat mempertanyakan apakah perusahaan yang berorientasi pada usaha memaksimalisasi keuntungan-keuntungan ekonomis memiliki komitmen moral untuk mendistribusi keuntungan-keuntungannya membangun masyarakat lokal, karena seiring waktu masyarakat tak sekedar menuntut perusahaan untuk menyediakan barang dan jasa yang diperlukan, melainkan juga menuntut untuk bertanggung jawab sosial.

Penerapan program CSR merupakan salah satu bentuk implementasi dari konsep tata kelola perusahaan yang baik (Good Coporate Governance). Diperlukan tata kelola perusahaan yang baik (Good Corporate Governance) agar perilaku pelaku bisnis mempunyai arahan yang bisa dirujuk dengan mengatur hubungan seluruh kepentingan pemangku kepentingan (stakeholders) yang dapat dipenuhi secara proporsional, mencegah kesalahan-kesalahan signifikan dalam strategi korporasi dan memastikan kesalahan-kesalahan yang terjadi dapat diperbaiki dengan segera.

Dengan pemahaman tersebut, maka pada dasarnya CSR memiliki fungsi atau peran strategis bagi perusahaan, yaitu sebagai bagian dari manajemen risiko khususnya dalam membentuk katup pengaman sosial (social security). Selain itu, melalui CSR perusahaan juga dapat membangun reputasinya, seperti meningkatkan citra perusahaan maupun pemegang sahamnya, posisi merek perusahaan, maupun bidang usaha perusahaan.

Dalam hal ini perlu ditegaskan bahwa CSR berbeda dengan charity atau sumbangan sosial. CSR harus dijalankan 
di atas suatu program dengan memerhatikan kebutuhan dan keberlanjutan program dalam jangka panjang. Sementara sumbangan sosial lebih bersifat sesaat dan berdampak sementara. Semangat CSR diharapkan dapat mampu membantu menciptakan keseimbangan antara perusahaan, masyarakat dan lingkungan. Pada dasarnya tanggung jawab sosial perusahaan ini diharapkan dapat kembali menjadi budaya bagi bangsa Indonesia khususnya, dan masyarakat dunia dalam kebersamaan mengatasi masalah sosial dan lingkungan.

Keputusan manajemen perusahaan untuk melaksanakan program-program CSR secara berkelanjutan, pada dasarnya merupakan keputusan yang rasional. Sebab implementasi program-program CSR akan menimbulkan efek lingkaran emas yang akan dinikmati oleh perusahaan dan seluruh stakeholder-nya. Melalui CSR, kesejahteraan dan kehidupan sosial ekonomi masyarakat lokal maupun masyarakat luas akan lebih terjamin. Kondisi ini pada gilirannya akan menjamin kelancaran seluruh proses atau aktivitas produksi perusahaan serta pemasaran hasil-hasil produksi perusahaan. Sedangkan terjaganya kelestarian lingkungan dan alam selain menjamin kelancaran proses produksi juga menjamin ketersediaan pasokan bahan baku produksi yang diambil dari alam.

Bila CSR benar-benar dijalankan secara efektif maka dapat memperkuat atau meningkatkan akumulasi modal sosial dalam rangka meningkatkan kesejahteraan masyarakat. Modal sosial, termasuk elemen-elemennya seperti kepercayaan, kohesifitas, altruisme, gotong royong, jaringan dan kolaborasi sosial memiliki pengaruh yang besar terhadap pertumbuhan ekonomi. Melalui beragam mekanismenya, modal sosial dapat meningkatkan rasa tanggung jawab terhadap kepentingan publik, meluasnya partisipasi dalam proses demokrasi, menguatnya keserasian masyarakat dan menurunnya tingkat kekerasan dan kejahatan. 
Tanggung jawab perusahaan terhadap kepentingan publik dapat diwujudkan melalui pelaksanaan programprogram CSR yang berkelanjutan dan menyentuh langsung aspek-aspek kehidupan masyarakat. Dengan demikian realisasi program-program CSR merupakan sumbangan perusahaan secara tidak langsung terhadap penguatan modal sosial secara keseluruhan. Berbeda halnya dengan modal finansial yang dapat dihitung nilainya kuantitatif, maka modal sosial tidak dapat dihitung nilainya secara pasti. Namun demikian, dapat ditegaskan bahwa pengeluaran biaya untuk program-program CSR merupakan investasi perusahaan untuk memupuk modal sosial.

Program CSR sudah mulai bermunculan di Indonesia seiring telah disahkannya Undang-Undang Nomor 40 Tahun 2007 tentang Perseroan Terbatas dan UndangUndang Nomor 25 Tahun 2007 tentang Penanaman Modal, adapun isi Undang-Undang tersebut yang berkaitan dengan CSR, yaitu:

Pada pasal 74 di Undang-Undang Nomor 40 Tahun 2007, berbunyi:

a. Perseroan yang menjalankan kegiatan usahanya di bidang dan/atau berkaitan dengan sumber daya alam wajib melaksanakan Tanggung Jawab Sosial dan Lingkungan.

b. Tanggung Jawab Sosial dan Lingkungan sebagaimana dimaksud pada ayat (1) merupakan kewajiban Perseroan yang dianggarkan dan diperhitungkan sebagai biaya Perseroan yang pelaksanaannya dilakukan dengan memperhatikan kepatutan dan kewajaran.

c. Perseroan yang tidak melaksanakan kewajiban sebagaimana dimaksud pada ayat (1) dikenai sanksi sesuai dengan ketentuan peraturan perundang-undangan.

d. Ketentuan lebih lanjut mengenai Tanggung Jawab Sosial dan Lingkungan diatur dengan Peraturan Pemerintah. 


\section{Tujuan nilai cost and benefit CSR}

CSR akan lebih berdampak positif bagi masyarakat, ini akan sangat tergantung dari orientasi dan kapasitas lembaga dan organisasi lain, terutama pemerintah. Studi Bank Dunia (Howard Fox, 2002) menunjukkan, peran pemerintah yang terkait dengan CSR meliputi pengembangan kebijakan yang menyehatkan pasar, keikutsertaan sumber daya, dukungan politik bagi pelaku CSR, menciptakan insentif dan peningkatan kemampuan organisasi. Untuk Indonesia, bisa dibayangkan, pelaksanaan CSR membutuhkan dukungan pemerintah daerah, kepastian hukum, dan jaminan ketertiban sosial. Pemerintah dapat mengambil peran penting tanpa harus melakukan regulasi di tengah situasi hukum dan politik saat ini. Di tengah persoalan kemiskinan dan keterbelakangan yang dialami Indonesia, pemerintah harus berperan sebagai koordinator penanganan krisis melalui CSR (Corporate Social Responsibilty). Pemerintah bisa menetapkan bidang-bidang penanganan yang menjadi fokus, dengan masukan pihak yang kompeten. Setelah itu, pemerintah memfasilitasi, mendukung, dan memberi penghargaan pada kalangan bisnis yang mau terlibat dalam upaya besar ini. Pemerintah juga dapat mengawasi proses interaksi antara pelaku bisnis dan kelompok-kelompok lain agar terjadi proses interaksi yang lebih adil dan menghindarkan proses manipulasi atau pengancaman satu pihak terhadap yang lain.

Intinya manfaat CSR bagi masyarakat yaitu dapat mengembangkan diri dan usahanya sehingga sasaran untuk mencapai kesejahteraan tercapai.

a. Meningkatkan Citra Perusahaan

Dengan melakukan kegiatan CSR, konsumen dapat lebih mengenal perusahaan sebagai perusahaan yang selalu melakukan kegiatan yang baik bagi masyarakat. 
b. Memperkuat "Brand" Perusahaan

Melalui kegiatan memberikan product knowledge kepada konsumen dengan cara membagikan produk secara gratis, dapat menimbulkan kesadaran konsumen akan keberadaan produk perusahaan sehingga dapat meningkatkan posisi brand perusahaan.

c. Mengembangkan Kerja Sama dengan Para Pemangku Kepentingan

Dalam melaksanakan kegiatan CSR, perusahaan tentunya tidak mampu mengerjakan sendiri, jadi harus dibantu dengan para pemangku kepentingan, seperti pemerintah daerah, masyarakat, dan universitas lokal. Maka perusahaan dapat membuka relasi yang baik dengan para pemangku kepentingan tersebut.

d. Membedakan Perusahaan dengan Pesaingnya

Jika CSR dilakukan sendiri oleh perusahaan, perusahaan mempunyai kesempatan menonjolkan keunggulan komparatifnya sehingga dapat membedakannya dengan pesaing yang menawarkan produk atau jasa yang sama.

5. Menghasilkan Inovasi dan Pembelajaran untuk Meningkatkan Pengaruh Perusahaan

Memilih kegiatan CSR yang sesuai dengan kegiatan utama perusahaan memerlukan kreativitas. Merencanakan CSR secara konsisten dan berkala dapat memicu inovasi dalam perusahaan yang pada akhirnya dapat meningkatkan peran dan posisi perusahaan dalam bisnis global.

\section{F. Rangkuman}

Pengertian inklusi digunakan sebagai sebuah pendekatan untuk membangun dan mengembangkan sebuah lingkungan yang semakin terbuka; mengajak masuk dan mengikutsertakan semua orang dengan berbagai perbedaan latar belakang, karakteristik, kemampuan, status, kondisi, etnik, budaya dan lainnya.

Inklusi keuangan memiliki banyak manfaat. Menurut Bank Dunia, peningkatan inklusi keuangan dengan nilai satu 
persen saja, maka pertumbuhan ekonomi bertambah 0,03 persen. Belum lagi efek lain dari inklusi keuangan dalam bentuk penciptaan lapangan pekerjaan, penurunan tingkat kemiskinan, hingga meminimalisir kesenjangan sosial.

CSR adalah suatu tindakan atau konsep yang dilakukan oleh perusahaan sebagai bentuk tanggung jawab mereka terhadap sosial atau lingkungan sekitar dimana perusahaan itu berada. Sedangkan definisi CSR menurut World Business Council on Sustainable Development adalah komitmen dari bisnis/perusahaan untuk berperilaku etis dan berkontribusi terhadap pembangunan ekonomi yang berkelanjutan, seraya meningkatkan kualitas hidup karyawan dan keluarganya, komunitas lokal dan masyarakat luas. Wacana Tanggung Jawab Sosial Perusahaan (Corporate Social Responsibility) yang kini menjadi isu sentral yang semakin populer dan bahkan ditempatkan pada posisi yang penting, karena itu kian banyak pula kalangan dunia usaha dan pihak-pihak terkait mulai merespon wacana ini, tidak sekedar mengikuti tren tanpa memahami esensi dan manfaatnya.

Intinya manfaat CSR bagi masyarakat yaitu dapat mengembangkan diri dan usahanya sehingga sasaran untuk mencapai kesejahteraan tercapai.

1. Meningkatkan Citra Perusahaan

2. Memperkuat "Brand" Perusahaan

3. Mengembangkan Kerja Sama dengan Para Pemangku Kepentingan

4. Membedakan Perusahaan dengan Pesaingnya

5. Menghasilkan Inovasi dan Pembelajaran untuk Meningkatkan Pengaruh Perusahaan

\section{G. Evaluasi}

1. Jelaskan inklusi!

2. Jelaskan tujuan inklusi!

3. Jelaskan pengertian nilai cost and benefit csr!

4. Jelaskan tujuan nilai cost and benefit csr! 


\section{Daftar Pustaka}

Arief Reza Farah Margareta, 2015, Tingkat Literasi Keuangan pada Mahasiswa

S1 Fakultas Ekonomi Vol. 17, No 1, Jakarta: JMK.

Sugiarto Agus, 2017, Siaran Pers Revisit Snlki Sebagai Upaya Akselerasi

Pencapaian Indeks Literasi dan Inklusi Keuangan, t.p.

Sugiono, 2015, Metode Penelitian Pendidikan, Bandung: Alfabeta

Umar Azwar Iskandar, 2017, Index Of Syariah Financial Inclution In Indonesia,

Article Financial Education And Training Agency, $\mathrm{t}$ 


\section{BAB II \\ INKLUSI KEUANGAN DAN NILAI COST AND BENEFIT CSR}

\section{A. Tujuan Umum}

Memahami materi ini sangat bermanfaat bagi mahasiswa untuk mengerti tentang Inklusi Keuangan

\section{B. Tujuan Khusus}

Setelah mempelajari bab ini, mahasiswa diharapkan dapat:

1. Menjelaskan pengertian Inklusi Keuangan

2. Menjelaskan gerakan Inklusi Keuangan

3. Menjelaskan tujuan Inklusi Keuangan

4. Menjelaskan pengertian nilai cost and benefit CSR

5. Menjelaskan tujuan nilai cost and benefit CSR

6. Menjelaskan karakteristik nilai cost and benefit CSR

7. Menjelaskan Keuntungan nilai cost and benefit CSR

\section{Kata Kunci}

Definisi Inklusi Keuangan, kriteria Inklusi Keuangan, klasifikasi Inklusi Keuangan.

\section{Media Pembelajaran}

Dalam bab ini media pembelajaran yang digunakan meliputi: white board, spidol, LCD, computer

\section{E. Uraian Materi}

\section{Pengertian inklusi keuangan}

Inklusi keuangan, maka berbicara juga tentang ketimpangan ekonomi dan literasi ekonomi masyarakat terhadap keuangan. Menurut Bank Dunia dalam laman resminya, mengartikan inklusi keuangan sebagai individu atau bisnis yang mempunyai akses untuk mempunyai keuangan yang cukup mampu untuk membeli barang atau jasa dengan cara yang efektif dan berkelanjutan. Sederhananya seperti ini, inklusi keuangan menunjukkan jumlah atau keadaan masyarakat yang menggunakan produk 
layanan jasa keuangan seperti pinjaman, teknologi finansial, perbankan, asuransi, dan produk keuangan lainnya. Oleh karena itu inklusi keuangan membutuhkan literasi keuangan dimana masyarakat memahami pentingnya menggunakan produk layanan keuangan dan juga proses keuangan lainnya sehingga masyarakat tidak lagi memiliki kecurigaan atau skeptisme terhadap produk layanan keuangan.

Selain itu, inklusi keuangan juga dapat mengurangi ketimpangan ekonomi di masyarakat karena akses layanan keuangan yang merata. Dengan inklusi keuangan, masyarakat diharapkan dapat mengakses layanan keuangan secara merata dan dapat memanfaatkan layanan produk dengan baik.

Di Indonesia sendiri, menurut Otoritas Jasa Keuangan per-November 2019 terdapat peningkatan inklusi dan literasi keuangan. Indek literasi keuangan di Indonesia memang belum bisa dikatakan baik, baru mencapai $38 \%$, sedangkan indek inklusi keuangan mencapai $76,19 \%$. Hal ini tentu jauh lebih baik dibanding tahun 2016 dimana tingkat literasi keuangan hanya mencapai $29,7 \%$ dan inklusi keuangan sebesar $67,8 \%$.

\section{Gerakan inklusi keuangan}

Menabung menjadi tanda dari berjalannya inklusi keuangan. Gerakan "Ayo Menabung" yang dikampanyekan OJK merupakan cara agar masyarakat terdorong untuk memakai layanan keuangan (finansial/perbankan). Apa saja gerakan-gerakan menabung yang sudah berjalan di Indonesia?

\section{Menabung di SimPel/SimPel iB}

SimPel yang merupakan singkatan dari Simpanan Pelajar merupakan bentuk tabungan yang dikhususkan untuk pelajar. Tabungan SimPel tersedia di banyak bank nasional di Indonesia, seperti Mandiri, BNI, BRI, BCA, BTN, Bank Permata, BJB, dan Bank Jatim. 
Selain itu, beberapa bank syariah juga menyediakannya, seperti Muamalat, Bank Syariah Mandiri, BRI Syariah, BNI Syariah, BCA Syariah, dan Bank Panin Syariah. Membuka Tabungan SimPel terbilang mudah dan menguntungkan karena:

a. Setoran awal yang ringan dimulai dari Rp5.000.

b. Setoran selanjutnya minimal Rp1.000.

c. Bebas biaya administrasi bulanan.

d. Saldo maksimum tidak dibatasi.

e. Rekening tidak lagi aktif bila tidak bertransaksi selama 12 bulan berturut-turut. Maka, akan dikenai biaya penalti saat berstatus dormant yang ringan hanya Rp1.000 per bulan. Penarikan, penyetoran, atau pindah buku dilayani di sekolah dan semua chanel Fitur sederhana dan menarik serta disesuaikan dengan kebutuhan pelajar. Perbedaan yang tampak jelas dari Tabungan SimPel dengan tabungan pada umumnya adalah tidak adanya bunga sebagai keuntungan pada Tabungan SimPel. Sebagai gantinya, ada program reward sesuai ketentuan bank.

\section{Yuk Nabung Saham}

Dikampanyekan Bursa Efek Indonesia (BEI), "Yuk Nabung Saham" merupakan cara menarik minat masyarakat untuk berinvestasi di pasar modal dengan secara teratur membeli saham. Berangkat dari data September 2015, jumlah investor aktif di Indonesia saat itu sebesar 30\%. Melihat fakta itulah BEI kemudian melakukan kampanye yang kemudian dikenal sebagai "Yuk Nabung Saham". Sejak kampanye "Yuk Nabung Saham" dari data Desember 2016, jumlah investor aktif di Indonesia meningkat menjadi 35\% dari total investor pasar modal di Indonesia.

Ada sejumlah alasan menurut BEI kenapa menabung saham itu menguntungkan. Tahan terhadap inflasi. Menyelamatkan masa depan karena keuntungannya terus bertumbuh. Mewujudkan keinginan dengan return yang dida- 